\title{
Social Acceptance of Wind Energy in Urban Landscapes
}

\author{
Mika Westerlund
}

\author{
" The restart of our economy needs to be green. It also needs to be equitable. It \\ needs to be inclusive." \\ Chrystia Freeland \\ Finance Minister of Canada \\ on COVID-19 recovery plan
}

\begin{abstract}
Although wind energy has high potential as a sustainable energy source to fight climate change, and the post COVID-19 world may require accelerated transition to renewable energy systems, many wind energy projects nevertheless face community resistance. Research on social acceptance of wind energy has increased rapidly, but understanding still lacks regarding the different types of acceptance, whether or not the acceptance correlates with demographics, and what drives acceptance of wind farms in the urban landscape. Our analysis of 2,376 residents in Helsinki, the capital of Finland, focused on the gaps in understanding and identified three groups of people: Protagonists, Centrists, and Antagonists. While Protagonists are highly positive about wind energy projects in the city, Antagonists oppose them, and Centrists adopt a middle-of-the-road approach. Further, three factors matter for social acceptance in urban landscapes: 1) distance, as residents prefer offshore wind farms to be farther away from the city's inhabitants, 2) gender, as women are more accepting of wind energy compared with men, and outright opponents of wind energy are more likely men, and 3) participation, as residents wish to participate in decision-making processes regarding wind farms, but lack interest in having ownership of and responsibility for wind energy projects. The study discusses the implications of these findings for developers and policymakers of wind energy projects in the urban context.
\end{abstract}

\section{Introduction}

Promoting renewable energy has recently become a global priority to fight climate change (Hevia-Koch \& Ladenburg, 2019; Liebe \& Dobers, 2019; Sharpton et al. 2020). In particular, wind energy has been hailed as a promising clean energy technology for transition to post-fossil carbon-based societies (Caporale \& De Lucia, 2015; Yuan et al., 2015; Hammami et al., 2016). News media (for example, Twidale, 2020) have reported that renewable energy has increased its share of global electricity production during the COVID-19 pandemic, thereby paving the way for a wide-scale transition away from fossil fuels to a decarbonized post-pandemic economy.
Transition to renewables such as wind energy, however, requires substantial financial investments, technical adaptation, and acceptance by the local society (Scherhaufer et al., 2017; de Araujo \& de Freitas, 2008; Langer et al., 2018). Hence, there is a growing scholarly interest to study wind energy from the perspective of "social acceptance" (Hall et al., 2013; Langer et al., 2016; Rand \& Hoen, 2017). Low social acceptance results in delays, public protests, cost escalation, and sometimes the obstruction of wind energy projects (D'Souza \& Yiridoe, 2014; Reusswig et al., 2016; Bolwig et al., 2020), while increasing the risk of failing to reach environmental policy goals (Cohen et al., 2014). Thus, energy developers and policymakers need to understand social acceptance in order to ensure successful planning, 


\title{
Social Acceptance of Wind Energy in Urban Landscapes
}

\author{
Mika Westerlund
}

implementation, and operation of wind energy systems (Jobert et al., 2007; Landeta-Manzano et al., 2018).

Public opinion polls usually show high levels of support for wind energy (Aitken, 2010; Rand \& Hoen, 2017). Nevertheless, various factors, including sociodemographic characteristics such as age and gender, may affect the social acceptance of adopting renewable energy systems (Johansen \& Emborg, 2018). For example, older groups and women are found to have lower acceptance of wind farms (Azarova et al., 2019; Ólafsdóttir \& Sæpórsdóttir, 2019). According to Caporale and De Lucia (2015), women may be more sensitive to the aesthetic impact of wind farms to landscape; thus, the perceived impacts of wind farms on landscape warrant more research from the perspective of gender. On the other hand, Hoen et al. (2019) did not find support for the gender argument, and Liebe et al. (2017) suggest that the correlation between gender and wind energy acceptance varies by region. Nonetheless, the visual impacts of wind energy systems seem to be a common factor across regions and socio-demographic groups (de Araujo \& de Freitas, 2008; Firestone et al., 2018; Hallan \& Gonzalez, 2020). Further, since much of the research on wind energy acceptance focuses on rural areas (Khorsand et al. 2015; Lienhoop, 2018; Gebreslassie, 2020), more understanding is still needed in urban contexts (Zaunbrecher \& Ziefle, 2016).

The objectives of this study of wind farms in urban landscapes are to investigate, 1) the types of social acceptance, 2) whether acceptance correlates with gender, and 3) what drives social acceptance. The study applies explorative, quantitative research methods on a publicly available survey data set derived from an open data service in Finland. The analyzed data include 2,376 responses from Helsinki, the capital of Finland, to a survey about residents' perceptions of (hypothetical) wind farms in the city's landscape. In so doing, the study identifies different groups of people (for example, based on gender) that vary by acceptance, and discusses the key factors that matter for social acceptance of wind energy systems in urban landscapes. The results contribute to the extant literature on social acceptance of renewable energy systems (for example, Reusswig et al., 2016; Rand \& Hoen, 2017; Giordono et al., 2018; Bolwig et al., 2020; Leiren et al., 2020) by providing further evidence from the urban context regarding three highly debated areas in wind energy acceptance, namely a) the distance of wind farms from the city's inhabited coastal areas, b) the role of gender in acceptance, and c) the relevance of citizen participation in wind energy projects.

The paper is structured as follows. After this introduction, the paper reviews literature on social acceptance of wind energy and the visual impacts of wind energy systems on urban landscapes. The paper then describes the data and methods of analysis. Thereafter, it provides results from quantitative analyses, and, finally, concludes with a discussion on key findings, their contributions to theory and practice, as well as limitations and future research avenues.

\section{Literature review}

\section{Definition and levels of social acceptance}

Scholarly interest in "social acceptance" emerged in the 1980s when renewable energy developers noticed that the implementation of wind farms was facing notable opposition in communities, although the surveys conducted had suggested high levels of support (Wüstenhagen et al., 2007; Bolwig et al., 2020). Since then, it has become apparent that people can "accept" wind power, while it does not mean at the same time that they "support" installing wind farms in their city (Khorsand et al., 2015; Enevoldsen \& Sovacool, 2016). Dermont et al. (2017) distinguish between "acceptability" (characteristic), "acceptance" (passive behaviour), and "support" (active behavior) for positive behaviour toward renewable energy technologies. Similarly to the negative, Friedl and Reichl (2016) label the opposing behaviour as "rejection" (passive behaviour that does not lead to taking action) and "resistance" (active behaviour, such as protesting or not using a technology). In this paper, social acceptance is defined as "the lack of noticeable opposition and active resistance, and the abundance of passive tolerance and positive attitudes, leading to support from majority for adopting low-carbon technology in a community" (Cohen et al., 2014; Khorsand et al., 2015; Wolsink, 2018).

While social acceptance can be examined at various levels, including macro (country), meso (city), or micro (individual) (Upham et al., 2015), it cannot be explained by any single factor. Rather, social acceptance combines individual and collective preferences that are rooted with economic, political, cultural, linguistic, and other social aspects (Scherhaufer et al., 2017). Further, Azarova et al. (2019) argue that social acceptance of renewable energy is not only about accepting a specific energy technology, or locally installing it, but also about the acceptance of administrative, technological, and social elements that come with it. Nevertheless, most studies 


\section{Social Acceptance of Wind Energy in Urban Landscapes}

\section{Mika Westerlund}

Table 1. Factors affecting acceptance of wind energy

\begin{tabular}{|c|c|c|}
\hline Factor & Examples & References \\
\hline Social & $\begin{array}{l}\text { Social interaction; potential conflicts with others } \\
\text { in the community; impact on the social image } \\
\text { and attractiveness of the community; social } \\
\text { welfare; community ties and trust toward } \\
\text { unfamiliar actors such as energy developers; } \\
\text { perception of peer acceptance of wind energy }\end{array}$ & $\begin{array}{l}\text { Sovacool \& Ratan (2012), Hall et al. (2013), } \\
\text { Yuan et al. (2015), Walker et al. (2018), } \\
\text { Suškevičs et al. (2019), Diogenes et al. (2020) }\end{array}$ \\
\hline Environmental & $\begin{array}{l}\text { Ecological change versus green benefits; adverse } \\
\text { impacts of wind turbines on biodiversity (flora } \\
\text { and fauna, wildlife, including felling of trees and } \\
\text { hazards of turbine blades to birds); impacts on } \\
\text { cliffs and other natural formations; recyclability } \\
\text { of metals and parts used in wind turbines }\end{array}$ & $\begin{array}{l}\text { Enevoldsen \& Sovacool (2016), Zaunbrecher \& } \\
\text { Ziefle (2016), Rand \& Hoen (2017), Roddis et al. } \\
\text { (2018), Suškevičs et al. (2019), Bolwig et al. } \\
(2020), \text { Caporale et al. (2020), Jørgensen et al. } \\
(2020)\end{array}$ \\
\hline Economic & $\begin{array}{l}\text { Installation and maintenance costs; economic } \\
\text { feasibility; financial situation of the community; } \\
\text { foreign direct investments; increased } \\
\text { employment opportunities; impacts on tourism; } \\
\text { consumer costs vs. monetary compensation and } \\
\text { government subsidies; negative impact on } \\
\text { property values; energy price; impact on taxes }\end{array}$ & $\begin{array}{l}\text { Khorsand et al. (2015), Spiess et al. (2015), } \\
\text { Yuan et al. (2015), Enevoldsen \& Sovacool } \\
\text { (2016), Bhowmik et al. (2018), Roddis et al. } \\
\text { (2018), Hoen et al. (2019), Ólafsdóttir \& } \\
\text { Sæpórsdóttir (2019), Bolwig et al. (2020), } \\
\text { Caporale et al. (2020), Diogenes et al. (2020), } \\
\text { Jørgensen et al. (2020), Kim et al. (2020), Leiren } \\
\text { et al. (2020) }\end{array}$ \\
\hline Technical & $\begin{array}{l}\text { Operational life of the system; performance and } \\
\text { functional efficiency; reliability, capacity and } \\
\text { energy supply security; system constraints; need } \\
\text { for transmission lines and pylons; changes in } \\
\text { grid infrastructure; distance of turbines to } \\
\text { residence; physical appearance such as the } \\
\text { design, type of movement, and the size of } \\
\text { turbines; number of turbines in the area; } \\
\text { interference with TV, radio, or mobile } \\
\text { communications }\end{array}$ & $\begin{array}{l}\text { Spiess et al. (2015), Westerberg et al. (2015), } \\
\text { Enevoldsen \& Sovacool (2016), Langer et al. } \\
\text { (2016), Zaunbrecher \& Ziefle (2016), Bhowmik } \\
\text { et al. (2018), Landeta-Manzano et al. (2018), } \\
\text { Langer et al. (2018), Roddis et al. (2018), Hoen } \\
\text { et al. (2019), Caporale et al. (2020), Diogenes et } \\
\text { al. (2020), Leiren et al. (2020) }\end{array}$ \\
\hline Institutional & $\begin{array}{l}\text { Political commitment; favorable regulations and } \\
\text { legal frameworks; sufficient information sharing; } \\
\text { transparency of governmental institutions and } \\
\text { processes; prevalence or lack of innovative } \\
\text { culture; engagement of local actors; public } \\
\text { involvement in decision-making; perceived } \\
\text { distributional fairness (how well the benefits, } \\
\text { risks and costs are distributed within the } \\
\text { community), procedural justice (how open, fair } \\
\text { and unbiased the decision-making and planning } \\
\text { processes are) }\end{array}$ & $\begin{array}{l}\text { Sovacool \& Ratan (2012), Hall et al. (2013), } \\
\text { Cohen et al. (2014), Walker et al. (2014), } \\
\text { Khorsand et al. (2015), Langer et al. (2016), } \\
\text { Scherhaufer et al. (2017), Sonnberger \& Ruddat } \\
\text { (2017), Johansen \& Emborg (2018), Hoen et al. } \\
\text { (2019), Vuichard et al. (2019), Bolwig et al. } \\
\text { (2020), Caporale et al. (2020), Diogenes et al. } \\
\text { (2020), Jørgensen et al. (2020) }\end{array}$ \\
\hline Health & $\begin{array}{l}\text { Noise and acoustic pollution; infrasound; non- } \\
\text { ionizing radiation; physiological health effects } \\
\text { (e.g., headaches and dizziness), psychological } \\
\text { health effects (sleep disturbances and stress } \\
\text { from potential long-term health risks, annoyance } \\
\text { from flickering and shadowing), safety concerns } \\
\text { such as falling ice }\end{array}$ & $\begin{array}{l}\text { Songsore \& Buzzelli (2014), Khorsand et al. } \\
\text { (2015), Langer et al. (2016), Landeta-Manzano } \\
\text { et al. (2018), Langer et al. (2018), Ferreira et al. } \\
\text { (2019), Hoen et al. (2019), Kim \& Chung (2019), } \\
\text { Bolwig et al. (2020), Jørgensen et al. (2020), } \\
\text { Leiren et al. (2020) }\end{array}$ \\
\hline Contextual & $\begin{array}{l}\text { Place-related visual impacts in terms of } \\
\text { aesthetics and visual appearance of the turbines; } \\
\text { visibility of the turbines at place of residence; } \\
\text { visual intrusion of the view; land occupation } \\
\text { needed for the project; place identity and } \\
\text { attachment, altered landscapes, and landscape } \\
\text { destruction }\end{array}$ & $\begin{array}{l}\text { Jobert et al. (2007), Hall et al. (2013), D'Souza \& } \\
\text { Yiridoe (2014), Khorsand et al. (2015), } \\
\text { Enevoldsen \& Sovacool (2016), Langer et al. } \\
\text { (2016), Zaunbrecher \& Ziefle (2016), Langer et } \\
\text { al. (2017), Rand \& Hoen (2017), Langer et al. } \\
\text { (2018), Ferreira et al. (2019), Hevia-Koch \& } \\
\text { Ladenburg (2019), Hoen et al. (2019), Kim \& } \\
\text { Chung (2019), Bolwig et al. (2020), Caporale et } \\
\text { al. (2020), Diogenes et al. (2020), Jørgensen et } \\
\text { al. (2020), Leiren et al. (2020) }\end{array}$ \\
\hline
\end{tabular}




\title{
Social Acceptance of Wind Energy in Urban Landscapes
}

\author{
Mika Westerlund
}

on renewable energy investigate social acceptance broadly as either "general acceptance", measuring general public attitudes toward a new energy technology, or as "local acceptance", focusing on specific situations where a local community is faced with installing a renewable energy system in their habitat (Emmerich et al., 2020). Studies that combine both are valuable because, while social acceptance affects the realization of national renewable energy policy targets (Bhowmik et al., 2018), it matters especially at the local level regarding site-related decisions for residents and city planners.

Previous literature on social acceptance of renewable energy systems (for example, Wüstenhagen et al., 2007; Sovacool \& Ratan, 2012; Caporale \& De Lucia, 2015; Hammami et al., 2016; Landeta-Manzano et al., 2018; Rand \& Hoen, 2017; Roddis et al., 2018; Bolwig et al., 2020; Devine-Wright \& Wiersma, 2020) suggests that social acceptance has three dimensions: 1) "Market acceptance" concerning investment needs, opportunities, and profits for investors, project developers, energy-suppliers, utilities and grid-owners, as well as changes in electricity costs for consumers and businesses. 2) "Socio-political acceptance" in terms of opinions of the energy technology as acceptable and useful, as well as the tone of the debate in the national media, politics, and public institutions. 3) "Community acceptance" including the activity and opinions of people and businesses living, working, and operating in the environment of specific energy projects and technology installations, who must therefore bear most of the direct external impacts.

Given that COVID-19 has pushed governments across the globe to stress the role of environmental sustainability in their economic recovery and growth plans (BNN Bloomberg, 2020; Janse \& Tsanova, 2020), it is now more than ever important to understand the factors that affect social acceptance or rejection of renewable energy.

\section{Factors affecting social acceptance or rejection of wind} energy systems

In general, social acceptance is affected by "perceived effects" (the risks, costs, and benefits of implementing renewable energy systems), as well as "perceived problems" (the adverse effects of relying on "traditional" energy sources). Such issues include CO2 emissions, waning fossil fuel reserves, and the risks of adopting nuclear power (Huijts et al., 2012; Walker et al., 2014; Gaede \& Rowlands, 2018). That said, general public opinion about wind energy has been typically positive (Ferreira et al. 2019; Hoen et al., 2019), while local opposition usually tends to hinge upon the selection of a particular site for wind farms (Caporale et al., 2020). Even though this paradox is sometimes explained with the increasingly unpopular concept of NIMBY ("Not In My Backyard"), which refers to one's own self-interests, it is likely more related to "place-protective" attitudes, associated with "place identity" and the emotions that connect people with particular places (Jami \& Walsh, 2017; Kim \& Chung, 2019).

In any case, more affects the acceptance of wind energy than a mere comparison of costs and benefits or one's self-interests. Previous research has identified various factors that influence the acceptance of wind energy systems: 1) social, 2) environmental, 3) economic, 4) technical, 5) institutional, 6) health, and 7) contextual. To provide a compact reference that has resulted from this research, Table 1 lists examples of these factors along with literature references.

\section{Visual impacts of wind farms on the urban landscape}

Wüstenhagen et al. (2007) argue that the impact of wind energy systems on local landscape is central for social acceptance. Landscape is defined as "a natural resource that provides social use and non-use benefits, and that has economic (land value) and non-economic (aesthetic) value to people" (Caporale \& De Lucia, 2015; Roddis et al., 2018). Indeed, Diogenes et al. (2020) and Spiess et al. (2015) note that concerns over visual impacts have surfaced as a primary reason for wind energy objections due to both economic value and aesthetic value reasons. Wind farms tend to turn a place of "romantic and unspoilt nature" into having the appearance of an "industrial space with artificial, mechanical and urban character" (Kim \& Chung, 2019; Ólafsdóttir \& Sæpórsdóttir, 2019). That said, after wind farm installation, communities often perceive that the wind turbines actually did not damage the scenic beauty of the area (Gebreslassie, 2020), and that turbines and their blades may even be perceived as aesthetically pleasant, creating a "postcard-like" landscape, thus having positive visual impacts (Kongprasit et al., 2017; Rand \& Hoen, 2017; Firestone et al., 2018).

Urban residents seem to be more supportive of wind energy than rural residents (Yuan et al., 2015), although acceptance decreases if wind turbines are installed nearby peoples' homes (Guo et al., 2015). That said, while a correlation between low acceptance and close proximity of wind farms to people's homes has been 


\title{
Social Acceptance of Wind Energy in Urban Landscapes
}

\author{
Mika Westerlund
}

suggested time and again, empirical evidence to prove this "proximity hypothesis" remains unconvincing (Harper et al., 2019; Hoen et al., 2019). Nonetheless, while remote off-shore installations may be more accepted than those nearby peoples' homes, due to limited visual and auditory impacts, the trade-off people face is higher financial requirements as a result of spatial distance and lack of grid connection (Devine-Wright \& Wiersma, 2020; Hall et al., 2013). Further, offshore windfarms have visual impacts on the seascape, especially from the perspective of recreational activities such as boating and yachting, as well as posing various environmental risks to birds and marine life from noise and vibration (Haggett, 2011; Guo et al., 2015; Westerberg et al., 2015; Kim et al., 2019). Thus, directly engaging local communities is essential to avoid long or failed planning processes, for both onshore and offshore wind power (Haggett, 2011; Bolwig et al., 2020; Lamy et al., 2020).

\section{Method}

\section{Data collection}

This study makes use of publicly available data from the "Wind Power Survey for Helsinki 2015", which was collected in Helsinki, Finland. The data set was obtained from the open data service "Helsinki Region Infoshare" (https://hri.fi/) under the Creative Commons Attribution 4.0 (CC-BY-4.0) license. The data set's maintainer is "Helsingin kaupunkiympäristön toimiala / Maankäytön yleissuunnittelu".

According to Sonnberger and Ruddat (2017), representative random samples, such as survey data in the present study, make a beneficial method for analyzing social acceptance of renewable energy. When investigating social acceptance of wind energy in the Finnish context, Jung et al. (2016) pointed out that Finland is among the top European Union member states in terms of using renewable energy sources, and is solidly on track to increase the share of renewables in order to reach both national and European Union's climate and energy targets. The Finnish government has agreed on a supplementary budget proposal for 2020 as part of its COVID-19 recovery package, in an effort to ensure "an economically, ecologically and socially sustainable emergence from the crisis", that aims to make "Finland the world's first carbon-neutral welfare state" (Evans \& Gabbatis, 2020).

The social context for this budgetary policy making situation in Finland is that the climate change hypothesis is largely accepted by Finnish people, while public attitudes toward both solar energy and wind energy are generally positive (Jung et al., 2016). A recent study by Suškevičs et al. (2019) shows that residents in Northern Europe, including those in Finland, have little concerns about the impacts of wind farms on their regional public image, but that instead people are concerned about visual impacts on their local landscape.

The initial data set contained anonymous responses from 2,426 respondents to an open online survey conducted in 2015. The survey focused on the social acceptance of wind energy in Helsinki, the capital and most populous city of Finland. Helsinki is in the south coast of the country, and has a population of 650,000 people, totaling 1.3 million people if including the city's urban area (Wikipedia, 2020). The vast majority (86\%) of respondents identified themselves as residents of Helsinki, while the rest did not identify their residence or were non-residents in the city (Helsingin kaupunki, 2015). Of note, Johansen (2019) found that residency influences place attachment and, therefore, people's perceptions of landscape change due to wind farm installations.

The survey included a total of 14 questions on citizen attitudes in four areas, indicated with a letter from A through $\mathrm{D}$, along with the number of questions in the results section of this study:

\section{A) What should Helsinki city do regarding wind energy?}

B) What kinds of effects would wind farms have on the city's image and landscape?

\section{C) Visibility and proper distance of wind turbines from the city's inhabited areas}

D) Respondent's willingness to participate in decision-making, consumption, and investments in wind energy.

\section{Data analysis}

To understand the relationship between demographics and social acceptance of wind energy in urban landscapes, only respondents who provided information on their gender were included. The final data set included 2,376 respondents of which 903 (38\%) were female and 1,473 (62\%) were male. This is like the gender distribution in many other survey-based studies on social acceptance of sustainable energy; for example, 


\section{Social Acceptance of Wind Energy in Urban Landscapes}

\section{Mika Westerlund}

Table 2. Wind energy acceptance in Helsinki by gender

\begin{tabular}{|c|c|c|c|c|c|}
\hline & & Female & Male & df & $\begin{array}{l}\text { t-value, } \\
\text { sig. }\end{array}$ \\
\hline & \multicolumn{5}{|c|}{ The city should... $\quad$ (1=totally disagree, $5=$ totally agree $)$} \\
\hline A01 & ... be an example in reducing $\mathrm{CO} 2$ gases & $\begin{array}{l}\mathrm{M}=4.67 \\
\mathrm{SD}=0.93\end{array}$ & $\begin{array}{l}\mathrm{M}=4.15 \\
\mathrm{SD}=1.43\end{array}$ & 2364.86 & $\begin{array}{l}10.719 \\
\mathrm{p}<0.001\end{array}$ \\
\hline \multirow[t]{2}{*}{ A02 } & ... produce wind power locally & $\begin{array}{l}\mathrm{M}=4.40 \\
\mathrm{SD}=1.23\end{array}$ & $\begin{array}{l}\mathrm{M}=3.88 \\
\mathrm{SD}=1.64\end{array}$ & 2283.69 & $\begin{array}{l}8.843 \\
\mathrm{p}<0.001\end{array}$ \\
\hline & \multicolumn{5}{|c|}{ Wind turbines would have a positive effect on ... $\quad(1=$ totally disagree, $5=$ totally agree $)$} \\
\hline B01 & ... the city's image & $\begin{array}{l}\mathrm{M}=4.44 \\
\mathrm{SD}=1.21\end{array}$ & $\begin{array}{l}\mathrm{M}=3.90 \\
\mathrm{SD}=1.61\end{array}$ & 2282.05 & $\begin{array}{l}9.418 \\
\mathrm{p}<0.001\end{array}$ \\
\hline \multirow[t]{2}{*}{ B02 } & ... the city's landscape & $\begin{array}{l}\mathrm{M}=3.73 \\
\mathrm{SD}=1.41\end{array}$ & $\begin{array}{l}\mathrm{M}=3.33 \\
\mathrm{SD}=1.66\end{array}$ & 2140.05 & $\begin{array}{l}6.285 \\
\mathrm{p}<0.001\end{array}$ \\
\hline & \multicolumn{5}{|c|}{$\begin{array}{l}\text { Attitude toward having wind turbines in the city if they are.... ( } 1 \text { =very negative, } 5=\text { very } \\
\text { positive) }\end{array}$} \\
\hline $\mathrm{C} 01$ & ... visible from the city's shipping lanes & $\begin{array}{l}\mathrm{M}=4.40 \\
\mathrm{SD}=1.15\end{array}$ & $\begin{array}{l}M=3.90 \\
\mathrm{SD}=1.54\end{array}$ & 2283.15 & $\begin{array}{l}9.001 \\
p<0.001\end{array}$ \\
\hline $\mathrm{C02}$ & ... visible from the city's world heritage site & $\begin{array}{l}\mathrm{M}=3.97 \\
\mathrm{SD}=1.38\end{array}$ & $\begin{array}{l}M=3.53 \\
S D=1.66\end{array}$ & 2172.55 & $\begin{array}{l}7.076 \\
\mathrm{p}<0.001\end{array}$ \\
\hline $\mathrm{C03}$ & ... built within the city's harbour area & $\begin{array}{l}\mathrm{M}=4.43 \\
\mathrm{SD}=1.18\end{array}$ & $\begin{array}{l}\mathrm{M}=3.82 \\
\mathrm{SD}=1.61\end{array}$ & 2302.08 & $\begin{array}{l}10.628 \\
\mathrm{p}<0.001\end{array}$ \\
\hline $\mathrm{C} 04$ & ... built on the city's landfill areas & $\begin{array}{l}\mathrm{M}=4.24 \\
\mathrm{SD}=1.27\end{array}$ & $\begin{array}{l}\mathrm{M}=3.73 \\
\mathrm{SD}=1.61\end{array}$ & 2225.40 & $\begin{array}{l}8.615 \\
\mathrm{p}<0.001\end{array}$ \\
\hline C05 & ... built within $8-10 \mathrm{~km}$ from the city's shore & $\begin{array}{l}\mathrm{M}=4.37 \\
\mathrm{SD}=1.20\end{array}$ & $\begin{array}{l}\mathrm{M}=3.90 \\
\mathrm{SD}=1.59\end{array}$ & 2272.48 & $\begin{array}{l}8.285 \\
\mathrm{p}<0.001\end{array}$ \\
\hline C06 & ... built within $4-5 \mathrm{~km}$ from the city's shore & $\begin{array}{l}\mathrm{M}=3.73 \\
\mathrm{SD}=1.44\end{array}$ & $\begin{array}{l}M=3.44 \\
S D=1.65\end{array}$ & 2106.69 & $\begin{array}{l}4.731 \\
\mathrm{p}<0.001\end{array}$ \\
\hline \multirow[t]{2}{*}{ C07 } & ... built within $1-2 \mathrm{~km}$ from the city's shore & $\begin{array}{l}M=3.50 \\
S D=1.54\end{array}$ & $\begin{array}{l}\mathrm{M}=3.14 \\
\mathrm{SD}=1.69\end{array}$ & 2036.22 & $\begin{array}{l}5.214 \\
\mathrm{p}<0.001\end{array}$ \\
\hline & \multicolumn{5}{|c|}{ How willing are you to ... $\quad(1=$ totally disagree, $5=$ totally agree $)$} \\
\hline D01 & ... influence on the location of wind turbines & $\begin{array}{l}\mathrm{M}=3.86 \\
\mathrm{SD}=1.15\end{array}$ & $\begin{array}{l}\mathrm{M}=4.10 \\
\mathrm{SD}=1.14\end{array}$ & 2374.00 & $\begin{array}{l}-4.876 \\
\mathrm{p}<0.001\end{array}$ \\
\hline D02 & ... buy locally produced wind power & $\begin{array}{l}\mathrm{M}=3.98 \\
\mathrm{SD}=1.36\end{array}$ & $\begin{array}{l}\mathrm{M}=3.28 \\
\mathrm{SD}=1.68\end{array}$ & 2201.52 & $\begin{array}{l}10.991 \\
\mathrm{p}<0.001\end{array}$ \\
\hline D03 & ... become a private investor in wind power & $\begin{array}{l}\mathrm{M}=2.93 \\
\mathrm{SD}=1.36\end{array}$ & $\begin{array}{l}M=2.93 \\
S D=1.56\end{array}$ & 2099.43 & $\begin{array}{l}-0.071 \\
p=0.943\end{array}$ \\
\hline
\end{tabular}

approximately a $40 \%$ female- $60 \%$ male proportion in Bhowmik et al. (2018), Guo et al. (2015), and Langer et al. (2017). However, according to Helsingin kaupunginkanslia (2020), the population of Helsinki in 2015 was $53 \%$ female- $47 \%$ male, thus suggesting that the sample has male dominance compared with the city's actual gender distribution. An equal split analysis of data to examine gender prevalence among early and late respondents did not suggest any selection bias $(\mathrm{p}=0.22)$.

The analysis here follows a recommendation by Bhowmik et al. (2018) to apply explorative techniques as a preferred approach to analyzing survey data in the social acceptance context. The data used for this study originally comprised responses to a number of attitudinal questions, measured on a 5-point Likert scale, where -2 equaled to "totally disagree" or "very negative" and +2 represented "totally agree" or "very positive". For the purposes of this study, the responses were rescaled to a range of 1 through 5 , to follow standard reporting style in academic research. The Likert-scale enabled this research to analyze the data using various explorative techniques, including t-tests for overall differences in means between men and women, cluster analysis for identifying several types of groups by their acceptance of wind energy, and crosstabulation for analyzing whether these groups vary by their gender distribution.

\section{Results}

An independent samples t-test analysis showed that women were more positive than men regarding all questions except their interest to participate in decisionmaking and become private investors in wind energy. In respect to these two questions, women were less interested to participate than men, and there was no difference between the genders in terms of their 


\section{Social Acceptance of Wind Energy in Urban Landscapes}

\section{Mika Westerlund}

investment willingness. Overall, both women and men were positive about installing wind energy farms in Helsinki, but neither of the genders was in the majority willing to become investors in such projects.

Although visibility of wind turbines from the city's inhabited areas was not deemed a major issue, both genders clearly preferred offshore turbines located farther away from the shore, suggesting that distance matters for the social acceptance of wind farms in urban contexts. Further, acceptance of having wind turbines near a city's world heritage site was clearly lower across both genders than if the turbines were installed in a more industrial area, such as the city's harbour or landfill areas (Table 2).

Next, we performed a K-means cluster analysis to identify groups of people in the sample by their type of wind energy social acceptance. K-means is a nonhierarchical clustering method in which the number of clusters has to be determined in advance (Steinley, 2006). After performing the analysis repeatedly with the number of clusters ranging from two to five, a threecluster solution was selected because it was reasonably balanced, easy to interpret, and theoretically meaningful. Each cluster was labeled in a manner that was deemed to best describe its characteristics. The three groups from the cluster analysis were labeled as 1) "Protagonists", which represented more than half of respondents, 2) "Centrists", and 3) "Antagonists". The latter two accounted fairly equally for the remainder of the sample's respondents. As table 3 illustrates, these three clusters varied significantly from each other.

"Protagonists" (Cluster 1) comprise people who show highly positive attitudes toward wind power. High values in all variables $(M=4.71, \quad S D=0.47)$ suggest that "Protagonists" think positively of having wind farms in their city, and that doing so would have a favourable effect on the city's image and landscape. They strongly promote the idea that their city should provide locally produced wind power, and lead by example in reducing carbon dioxide emissions. Further, "Protagonists" are not ignorant of the best locations for wind power, but rather accept wind turbines both offshore and onshore, including highly visible locations in and around the city, and even the world heritage site on nearby islands in front of the city's harbor area. "Protagonists" would also like to influence decision making in regard to the location of placement for wind turbines, and would like to consume locally-produced wind power even if it was more expensive than alternatives, as well invest financially in wind power at the personal level.

"Centrists" (Cluster 2) are people who, similarly to cluster 1 , have a generally positive attitude toward wind power, and consider it as a great way to improve the city's image, especially if the city provides an example to others by reducing CO2 emissions. However, "Centrists" take a middle-of-the-road approach $(\mathrm{M}=3.57, \mathrm{SD}=0.76)$ by being more conservative when it comes to the effects of wind turbines on the city's landscape. They are clearly

Table 3. Clusters and their characteristics

\begin{tabular}{|c|c|c|c|}
\hline & $\begin{array}{c}\text { Protagonists } \\
\text { (Cluster 1) }\end{array}$ & $\begin{array}{c}\text { Centrists } \\
\text { (Cluster 2) }\end{array}$ & $\begin{array}{c}\text { Antagonists } \\
\text { (Cluster 3) }\end{array}$ \\
\hline $\mathrm{n}=1342(56.5 \%)$ & $\mathrm{n}=550(23.1 \%)$ & $\mathrm{n}=484(20.4 \%)$ \\
\hline $\mathrm{A} 01$ & 5 & 5 & 2 \\
\hline $\mathrm{A} 02$ & 5 & 4 & 1 \\
\hline $\mathrm{B} 01$ & 5 & 4 & 1 \\
\hline $\mathrm{B} 02$ & 5 & 3 & 1 \\
\hline C01 & 5 & 4 & 2 \\
\hline C02 & 5 & 3 & 2 \\
\hline C03 & 5 & 4 & 2 \\
\hline C04 & 5 & 4 & 2 \\
\hline C05 & 5 & 4 & 1 \\
\hline C06 & 5 & 3 & 1 \\
\hline C07 & 4 & 2 & 4 \\
\hline D01 & 4 & 4 & 1 \\
\hline D02 & 4 & 3 & 1.57 \\
\hline D03 & 4 & 3 & 0.85 \\
\hline Mean & 4.71 & 3.57 & \\
\hline SD & 0.47 & 0.76 & \\
\hline
\end{tabular}




\section{Social Acceptance of Wind Energy in Urban Landscapes}

\section{Mika Westerlund}

pickier than "Protagonists" in regard to the locations for wind farms and are in favour of installing wind turbines farther offshore or on the city's landfill areas, or other less visible on-shore areas around the city. Further, "Centrists" are less prone to consume only locallyproduced wind energy given that it would be more expensive that alternatives, and less willing to personally invest in wind power projects. However, similar to "Protagonists", they are willing to participate in decision making regarding the location of wind turbine installments in and around the city.

"Antagonists" (Cluster 3) consist of people who are quite opposite to the other clusters regarding wind energy prospects $(\mathrm{M}=1.57, \mathrm{SD}=0.85)$. Put briefly, "Antagonists" are against the idea that Helsinki should build local wind power plants, and that having wind farms in the city's area would have positive effects on the city's image or landscape, especially when it comes to wind farm locations closer to the city's inhabited and other visible, non-industrial areas. They are rather against having wind turbines anywhere in the city, and would not consume locally-produced wind energy if cheaper alternatives are present, nor are they willing to invest in wind power projects at the personal level. "Antagonists" would however, equal to their counterparts in the other clusters, be interested to participate in decision-making regarding the location of wind turbines in the city. Of note, "Antagonists" were the smallest cluster, representing a mere one-fifth of the sample, whereas "Protagonists" represented more than half of respondents in the sample. Figure 1 illustrates the differences in cluster profiles between the three groups.

Finally, we cross-tabulated the data to find out if the three clusters differed from each other in terms of gender distribution. We used Pearson's Chi-Square $(\chi 2)$ to test for statistically significant differences between observed and expected frequencies in gender distribution between the groups. This test excluded the possibility that any differences would arise by chance.

Table 4 suggests that the three clusters differ in terms of their gender distribution $(\chi 2[2,2376]=77.83, \mathrm{p}<0.001)$. Bearing in mind that the gender distribution of the sample was $38 \%$ female and $62 \%$ male, the differences between the clusters become quite explicit. Both "Protagonists" ( $42 \%$ female, $58 \%$ male) and "Centrists" (43\% female, $57 \%$ male) include more women and fewer men than expected. Overall, almost 90 percent of all females in the sample fall into "Protagonists" and "Centrists", the two clusters that reflect positive or more positive views toward having wind energy in and around the city. Conversely, "Antagonists", who are characterized by negative or more negative attitudes toward wind energy, include significantly more men than women ( $21 \%$ female, $79 \%$ male), making the cluster distinctively male-dominated compared with the other clusters. While $20 \%$ of respondents in the whole sample represent "Antagonists", a total of $26 \%$ of all males in the sample fall into this cluster.

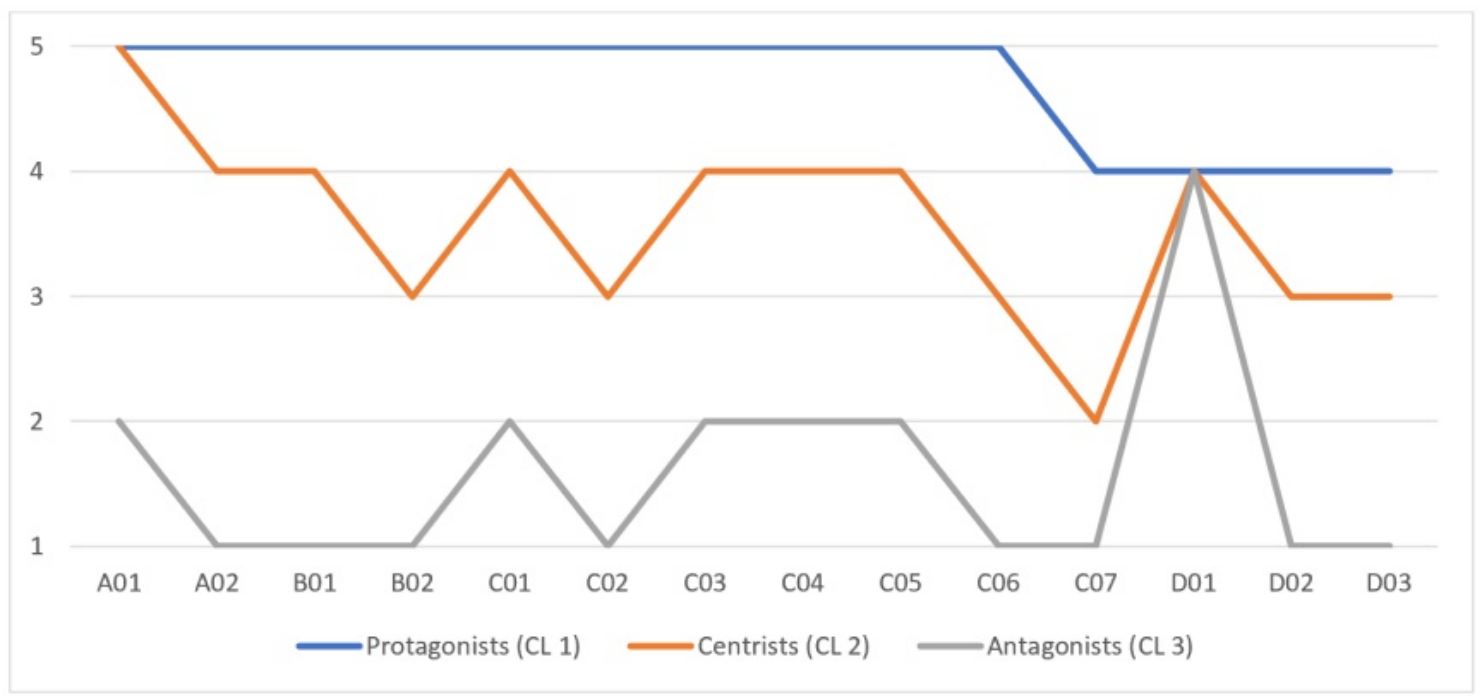

Figure 1. Illustration of cluster profiles 


\title{
Social Acceptance of Wind Energy in Urban Landscapes
}

\author{
Mika Westerlund
}

Table 4. Gender distribution within clusters

\begin{tabular}{|l|c|c|c|c|c|}
\hline Gender & $\mathbf{N}$ & Protagonists (CL 1) & Centrists (CL 2) & Antagonists (CL 3) & $\chi^{2}$ \\
\hline Female & 903 & $565 / 510(62.6 \%$, & $238 / 209(26.4 \%$, & $100 / 184(11.1 \%$, & \\
& & $42.1 \%)$ & $43.3 \%)$ & $20.7 \%$ & 77.83 \\
\cline { 1 - 6 } Male & 1,473 & $777 / 832(52.7 \%$, & $312 / 341(21.2 \%$, & $384 / 300(26.1 \%$, & $*$ \\
& & $57.9 \%)$ & $56.7 \%)$ & $79.3 \%)$ & \\
\hline
\end{tabular}

Note: observed/expected value, (\% within gender, \% within cluster), $\mathrm{N}=2376, \mathrm{df}=2,{ }^{*} \mathrm{p}<0.001$

\section{Discussion}

This study has aimed to understand the different types of social acceptance, whether acceptance correlates with demographics, and what drives social acceptance of wind farms in urban landscapes. The analysis based on open sourced survey data from 2,376 residents in Helsinki, Finland, identified three groups of people by their acceptance or rejection of wind energy systems: "Protagonists", "Centrists", and "Antagonists". These groups represent different types of social acceptance. "Protagonists" have highly supportive and positive attitudes toward wind energy. "Centrists" also adopting a positive but more moderate approach. "Antagonists" show explicitly negative and oppositional attitudes to wind energy.

While women were predominantly represented among "Protagonists" and "Centrists", the opposing group of "Antagonists" was distinctively male-dominated. The three groups differed on almost every investigated factor, while all of them wanted to participate in decision-making processes related to wind energy projects in and around the city. Overall, three factors seem to matter for social acceptance of wind farms in urban landscapes: 1) distance of wind farms from inhabited coastal areas, 2) demographics in terms of gender, and 3) willingness to participate in decisionmaking processes related to wind energy projects.

\section{Contributions to theory and practice}

These results contribute to theory in several ways. First, the study contributes to the literature on social acceptance by showing once again that distance matters in wind energy acceptance. The farther wind farms are located away from inhabited coastal areas, the more accepting people are of them. Of note, the increased distance in this study was associated with installing offshore, rather than onshore wind turbines. Previous literature (for example, Harper et al., 2019; Hoen et al., 2019) only provided weak or controversial evidence on the role of distance in wind energy acceptance. This study thus provides empirical support for the "proximity hypothesis", while keeping in mind Leiren et al.'s (2020) argument that distance itself does not matter, but rather that reducing the visual impact by increasing distance and visual awareness of the wind farms does. Also, the study partially validates previous literature that suggested the proximity of wind farms to protected areas and areas with high environmental, historical, or archaeological value are less accepted (Cohen et al., 2014; Leiren et al., 2020). In the present study, location of wind farms near the city's world heritage site was also not surprisingly less accepted than installing turbines in more industrial areas, such as nearer to the harbour.

Second, the results contribute to the debate on social acceptance by showing that gender demographics matter for wind energy acceptance. In the Finnish urban context, women come out as more supportive of wind energy than men. In this vein, the results here are in marked contrast with arguments by, for example, Azarova et al. (2019) and Ólafsdóttir and Sæpórsdóttir (2019), who found that women are less accepting of wind energy compared with men. In this research sample, the results were quite the opposite, and women were overrepresented in both clusters that support adoption of wind energy systems, as well as underrepresented in the cluster that opposes wind energy. Further, these results suggest that women are not significantly different from men in terms of having a (somewhat low) willingness to invest in wind energy. Notably, urban residents, in general, had higher investment willingness associated with their attitudes toward wind energy. Again, this finding contrasts with some previous literature. For example, Johansen and Emborg (2018) found that, overall, men are more willing to invest in sustainable energy systems, either to support sustainable energy or for economic gains. The specific motivational differences across genders were not covered by the current study.

Third, the results contribute to the literature on general social acceptance by confirming that there are different 


\title{
Social Acceptance of Wind Energy in Urban Landscapes
}

\author{
Mika Westerlund
}

types of acceptance, in this case with respect to wind energy. While previous literature tends to make a dichotomous distinction between proponents and opponents of wind energy, our results support the arguments by, for example, Aitken (2010) and Khorsand et al. (2015), who suggest that there are more nuanced distinctions between the dichotomies. In this sense, our results are in line with Gross (2007), who argued that there are three kinds of people in terms of their attitude toward wind energy (positive, neutral or negative), and Langer et al. (2018), who proposed three acceptance modes (active acceptance, ambivalence, active nonacceptance). Interestingly, our results suggest that the differences between the three groups are quite distinctive in all but one factor: willingness to participate in wind energy planning processes. This finding is novel in that it suggests all groups, including "Centrists", are quite certain about their opinions in the sense of being willing to actively influence public decision-making.

In terms of contributions to practice, in line with previous research (Bolwig et al., 2020; Giordono et al., 2018; Zaunbrecher \& Ziefle, 2016), the research suggests open consultation with the community, including transparent, comprehensive, and participatory processes in renewable energy projects can contribute to social acceptance, while a lack of such processes when discussing energy and the environment can contribute to conflicts. Renewable energy developers and policymakers should ensure that such participatory planning engages all members of community, including those who oppose wind energy. In fact, opponents of wind energy should be specifically addressed, not to mitigate their opposition by changing "wrong" attitudes into "right" attitudes, but rather because they may be asking for different types of "exchanges" than the rest of the community (Aitken, 2010; Groth \& Vogt, 2014).

For example, objectors tend to emphasize aesthetics compared to supporters of wind energy (Groth \& Vogt, 2014; Enevoldsen \& Sovacool, 2016). Hence, in order to increase social acceptance of wind energy systems in urban landscapes, energy developers and policy makers are advised to focus on finding ways to reduce the visual impacts of wind farms, rather than providing an unlikely community with increased opportunities to invest in wind energy projects. The possibilities for innovative transformation have become a topical notion as we live now during a pandemic, and hopefully soon shift to a post-COVID-19 world, where governments across the globe are planning to boost de-carbonization of their economies, in order to increase both human societal and environmental welfare.

\section{Limitations and Future Research}

This kind of open data research puts forward various challenges. First, the data has limitations given the fact that the survey was not designed, nor was the data collected by the author of this research paper. Wolsink (2018) emphasizes that, social acceptance being a set of processes, a researcher should examine all dimensions of social acceptance simultaneously, in order to understand the acceptance processes. In the present data set, the focus was on community acceptance and, thus, not all dimensions of social acceptance such as market and socio-political acceptance were covered. This is likely due to the specific research objectives of the City of Helsinki at the time of conducting their survey.

Second, previous research (for example, Aitken, 2010; Cohen et al., 2014; Enevoldsen \& Sonacool, 2016; Harper et al., 2019) has noted that in addition to sociodemographical factors, people's knowledge and experience of a technology also matters. Those without having had any experience with wind energy are more likely to oppose it. In contrast, this study relied on anonymous survey responses collected through an open online survey and published as open data. The data lacked information about respondents' level of knowledge and experience about wind energy technology, such as their political views, environmental self-identity, education, income, marital status, length of residence, and so forth.

Third, the survey covered visual impacts of wind farms, but did not utilize visual exposure to the spatial location of wind farms. Visual exposure, such as showing the respondents still images of wind turbines inserted into real photographs of their city, can influence social acceptance responses (Westerberg et al., 2015; HeviaKoch \& Ladenburg, 2019; Cranmer et al., 2020).

Future research should focus on the role of "place identity" (Hallan \& Gonzalez, 2020) in social acceptance of wind energy. Likewise, it should examine placerelated and other "deeper" values (Hammami et al., 2016) that people have, which can affect social acceptance or rejection of wind energy in an urban community. Research that advances further should investigate the connection between place identity and perceived visual impacts in the urban landscape. 


\title{
Social Acceptance of Wind Energy in Urban Landscapes
}

\author{
Mika Westerlund
}

\section{References}

Aitken, M. 2010. Why we still don't understand the social aspects of wind power: A critique of key assumptions within the literature. Energy Policy, 38(4): 1834-1841. https://doi.org/10.1016/j.enpol.2009.11.060

Azarova, V., Cohen, J., Friedl, C., \& Reichl, J. 2019. Designing local renewable energy communities to increase social acceptance: Evidence from a choice experiment in Austria, Germany, Italy, and Switzerland. Energy Policy, 132: 1176-1183.

https://doi.org/10.1016/j.enpol.2019.06.067

Bhowmik, C., Bhowmik, S., \& Ray, A. 2018. Social acceptance of green energy determinants using principal component analysis. Energy, 160: 1030-1046.

https://doi.org/10.1016/j.energy.2018.07.093

BNN Bloomberg. 2020. Freeland, Trudeau push for green recovery as finance portfolio changes hands. $B N N$ Bloomberg, August 19, 2020. [Available at: https://www.bnnbloomberg.ca/freeland-trudeaupush-for-green-recovery-as-finance-portfoliochanges-hands-1.1482039]

Bolwig, S., Bolkesjø, T.F., Klitkou, A., Lund, P.D., Bergaentzlé, C., Borch, K., Olsen, O.J., Kirkerud, J.G., Chen, Y.-K., Gunkel, P.A., \& Skytte, K. 2020. Climatefriendly but socially rejected energy-transition pathways: The integration of techno-economic and socio-technical approaches in the Nordic-Baltic region. Energy Research \& Social Science, 67, 101559. https://doi.org/10.1016/j.erss.2020.101559

Caporale, D., \& De Lucia, C. 2015. Social acceptance of on-shore wind energy in Apulia Region (Southern Italy). Renewable and Sustainable Energy Reviews, 52: 1378-1390.

https://doi.org/10.1016/j.rser.2015.07.183

Caporale, D., Sangiorgio, V., Amodio, A., \& De Lucia, C. 2020. Multi-criteria and focus group analysis for social acceptance of wind energy. Energy Policy, 140, 111387.

https://doi.org/10.1016/j.enpol.2020.111387

Cohen, J.J., Reichl, J., \& Schmidthaler, M. 2014. Refocussing research efforts on the public acceptance of energy infrastructure: A critical review. Energy, 76: 4-9.

https://doi.org/10.1016/j.energy.2013.12.056

Cranmer, A., Ericson, J.D., Broughel, A.E., Bernard, B., Robicheaux, E., \& Podolski, M. 2020. Worth a thousand words: Presenting wind turbines in virtual reality reveals new opportunities for social acceptance and visualization research. Energy Research \& Social Science, 67, 101507.

https://doi.org/10.1016/j.erss.2020.101507

de Araujo, M.S.M., \& de Freitas, M.A.V. 2008. Acceptance of renewable energy innovation in Brazil- case study of wind energy. Renewable and Sustainable Energy Reviews, 12(2): 584-591.

https://doi.org/10.1016/j.rser.2006.03.017
Dermont, C., Ingold, K., Kammermann, L., \& Stadelmann-Steffen, I. 2017. Bringing the policy making perspective in: A political science approach to social acceptance. Energy Policy, 108: 359-368. https://doi.org/10.1016/j.enpol.2017.05.062

Devine-Wright, P., \& Wiersma, B. 2020. Understanding community acceptance of a potential offshore wind energy project in different locations: An island-based analysis of 'place-technology fit'. Energy Policy, 137, 111086.

https://doi.org/10.1016/j.enpol.2019.111086

Diogenes, J.R.F., Claro, J., Rodrigues, J.C., \& Loureiro, M.V. 2020. Barriers to onshore wind energy implementation: A systematic review. Energy Research \& Social Science, $60,101337$.

https://doi.org/10.1016/j.erss.2019.101337

D'Souza, C., \& Yiridoe, E.K. 2014. Social acceptance of wind energy development and planning in rural communities of Australia: A consumer analysis. Energy Policy, 74: 262-270.

https://doi.org/10.1016/j.enpol.2014.08.035

Emmerich, P., Hülemeier, A.-G., Jendryczko, D., Baumann, M.J., Weil, M., \& Baur, D. 2020. Public acceptance of emerging energy technologies in context of the German energy transition. Energy Policy, 142, 111516.

https://doi.org/10.1016/j.enpol.2020.111516

Enevoldsen, P. \& Sovacool, B.K. 2016. Examining the social acceptance of wind energy: Practical guidelines for onshore wind project development in France. Renewable and Sustainable Energy Reviews, 53: 178184.

https://doi.org/10.1016/j.rser.2015.08.041

Evans, S., \& Gabbatiss, J. 2020. Coronavirus: Tracking how the world's 'green recovery' plans aim to cut emissions. Carbon Brief, June 16, 2020. [Available at: https://www.carbonbrief.org/coronavirus-trackinghow-the-worlds-green-recovery-plans-aim-to-cutemissions]

Ferreira, P., Lima, F., Ribeiro, F., \& Vieira, F. 2019. A mixed-method approach for the assessment of local community perception towards wind farms. Sustainable Energy Technologies and Assessments, 33: 44-52.

https://doi.org/10.1016/j.seta.2019.02.004

Firestone, J., Bidwell, D., Gardner, M., \& Knapp, L. 2018. Wind in the sails or choppy seas?: People-place relations, aesthetics and public support for the United States' first offshore wind project. Energy Research \& Social Science, 40: 232-243. https://doi.org/10.1016/j.erss.2018.02.017

Friedl, C., \& Reichl, J. 2016. Realizing energy infrastructure projects - A qualitative empirical analysis of local practices to address social acceptance. Energy Policy, 89: 184-193.

https://doi.org/10.1016/j.enpol.2015.11.027 


\title{
Social Acceptance of Wind Energy in Urban Landscapes
}

\author{
Mika Westerlund
}

Gaede, J., \& Rowlands, I.H. 2018. Visualizing social acceptance research: A bibliometric review of the social acceptance literature for energy technology and fuels. Energy Research \& Social Science, 40: 142-158. https://doi.org/10.1016/j.erss.2017.12.006

Gebreslassie, M.G. 2020. Public perception and policy implications towards the development of new wind farms in Ethiopia. Energy Policy, 139, 111318. https://doi.org/10.1016/j.enpol.2020.111318

Giordono, L.S., Boudet, H.S., Karmazina, A., Taylor, C.L., \& Steel, B.S. 2018. Opposition "overblown"? Community response to wind energy siting in the Western United States. Energy Research \& Social Science, 43: 119-131.

https://doi.org/10.1016/j.erss.2018.05.016

Gross, C. 2007. Community perspectives of wind energy in Australia: the application of a justice and community fairness framework to increase social acceptance. Energy Policy, 35(5): 2727-2736. https://doi.org/10.1016/j.enpol.2006.12.013

Groth, T.M., \& Vogt, C.A. 2014. Rural wind farm development: Social, environmental and economic features important to local residents. Renewable Energy, 63: 1-8.

https://doi.org/10.1016/j.renene.2013.08.035

Guo, Y., Ru, P., Su, J., \& Anadon, L.D. 2015. Not in my backyard, but not far away from me: Local acceptance of wind power in China. Energy, 82: 722-733.

https://doi.org/10.1016/j.energy.2015.01.082

Haggett, C. 2011. Understanding public responses to offshore wind power. Energy Policy, 39(2): 503-510. https://doi.org/10.1016/j.enpol.2010.10.014

Hall, N., Ashworth, P., \& Devine-Wright, P. 2013. Societal acceptance of wind farms: Analysis of four common themes across Australian case studies. Energy Policy, 58: 200-208.

https://doi.org/10.1016/j.enpol.2013.03.009

Hallan, C., \& González, A. 2020. Adaptive responses to landscape changes from onshore wind energy development in the Republic of Ireland. Land Use Policy, 97, 10475.

https://doi.org/10.1016/j.landusepol.2020.104751

Hammami, S.M., Chtourou, S., \& Triki, A. 2016. Identifying the determinants of community acceptance of renewable energy technologies: The case study of a wind energy project from Tunisia. Renewable and Sustainable Energy Reviews, 54: 151160.

https://doi.org/10.1016/j.rser.2015.09.037

Harper, M., Anderson, B., James, P.A.B., \& Bahaj, A.B. 2019. Onshore wind and the likelihood of planning acceptance: Learning from a Great Britain context. Energy Policy, 128: 954-966.

https://doi.org/10.1016/j.enpol.2019.01.002

Helsingin kaupunginkanslia. 2020. Helsinki: population. https://hri.fi/data/en_GB/dataset/helsinki-vaesto

Helsingin kaupunki. 2015. Tuulivoiman sosiaalinen hyväksyttävyys Helsingissä, 14.10.2015. Project report by Helsingin kaupunki - Kaupunkisuunnitteluvirasto, WSP \& Steep [in Finnish]

Hevia-Koch, P., \& Ladenburg, J. 2019. Where should wind energy be located? A review of preferences and visualisation approaches for wind turbine locations. Energy Research \& Social Science, 53: 23-33.

https://doi.org/10.1016/j.erss.2019.02.010

Hoen, B., Firestone, J., Rand, J., Elliot, D., Hübner, G., Pohl, J., Wiser, R., Lantz, E., Haac, T.R., \& Kaliski, K. 2019. Attitudes of U.S. Wind Turbine Neighbors: Analysis of a Nationwide Survey. Energy Policy, 134, 110981.

https://doi.org/10.1016/j.enpol.2019.110981

Huijts, N.M.A., Molin, E.J.E., \& Steg, L. 2012. Psychological factors influencing sustainable energy technology acceptance: A review-based comprehensive framework. Renewable and Sustainable Energy Reviews, 16(1): 525-531. https://doi.org/10.1016/j.rser.2011.08.018

Jami, A.A., \& Walsh, P.R. 2017. From consultation to collaboration: A participatory framework for positive community engagement with wind energy projects in Ontario, Canada. Energy Research \& Social Science, 27: 14-24. https://doi.org/10.1016/j.erss.2017.02.007

Janse, K.A., Tsanova, I. 2020. What we can learn from Europe's response to the COVID-19 crisis. World Economic Forum, August 10, 2020. [Available at: https://www.weforum.org/agenda/2020/08/europeresponse-covid-19-coronavirus-economic-crisiseuro-fiscal-monetary-policy-green-deal/]

Jobert, A., Laborgne, P., \& Mimler, S. 2007. Local acceptance of wind energy: Factors of success identified in French and German case studies. Energy Policy, 35(5): 2751-2760.

https://doi.org/10.1016/j.enpol.2006.12.005

Johansen, K., \& Emborg, J. 2018. Wind farm acceptance for sale? Evidence from the Danish wind farm coownership scheme. Energy Policy, 117: 413-422. https://doi.org/10.1016/j.enpol.2018.01.038

Johansen, K. 2019. Local support for renewable energy technologies? Attitudes towards local near-shore wind farms among second home owners and permanent area residents on the Danish coast. Energy Policy, 132: 691-701.

https://doi.org/10.1016/j.enpol.2019.04.027

Jørgensen, M.L., Anker, H.T., \& Lassen, J. 2020. Distributive fairness and local acceptance of wind turbines: The role of compensation schemes. Energy Policy, 138, 111294.

https://doi.org/10.1016/j.enpol.2020.111294

Jung, N., Moula, M.E., Fang, T., Hamdy, M., \& Lahdelma, R. 2016. Social acceptance of renewable energy technologies for buildings in the Helsinki Metropolitan Area of Finland. Renewable Energy, 99: 813-824.

https://doi.org/10.1016/j.renene.2016.07.006 


\title{
Social Acceptance of Wind Energy in Urban Landscapes
}

\author{
Mika Westerlund
}

Khorsand, I., Kormos, C., MacDonald, E.G., \& Crawford, C. 2015. Wind energy in the city: An interurban comparison of social acceptance of wind energy projects. Energy Research \& Social Science, 8: 66-77. https://doi.org/10.1016/j.erss.2015.04.008

Kim, E.-S., \& Chung, J.-B. 2019. The memory of place disruption, senses, and local opposition to Korean wind farms. Energy Policy, 131: 43-52.

https://doi.org/10.1016/j.enpol.2019.04.011

Kim, H.-J., Kim, J.-H., \& Yoo, S.-H. 2019. Social acceptance of offshore wind energy development in South Korea: Results from a choice experiment survey. Renewable and Sustainable Energy Reviews, 113, 109253.

https://doi.org/10.1016/j.rser.2019.109253

Kim, K.J., Lee, H., \& Koo, Y. 2020. Research on local acceptance cost of renewable energy in South Korea: A case study of photovoltaic and wind power projects. Energy Policy, 144, 111684.

https://doi.org/10.1016/j.enpol.2020.111684

Kongprasit, S., Waewsak, J., \& Chaichana, T. 2017. Wind Turbine and Local Acceptance in Southern Thailand. Energy Procedia, 138: 380-385.

https://doi.org/10.1016/j.egypro.2017.10.176

Lamy, J., de Bruin, W.B., Azevedo, I.M.L., \& Morgan, M.G. 2020. Keep wind projects close? A case study of distance, culture, and cost in offshore and onshore wind energy siting. Energy Research \& Social Science, $63,101377$. https://doi.org/10.1016/j.erss.2019.101377

Landeta-Manzano, B., Arana-Landin, G., Calvo, P.M., \& Heras-Saizarbitoria, I. 2018. Wind energy and local communities: A manufacturer's efforts to gain acceptance. Energy Policy, 121: 314-324. https://doi.org/10.1016/j.enpol.2018.05.034

Langer, K., Decker, T., Roosen, J., \& Menrad, K. 2016. A qualitative analysis to understand the acceptance of wind energy in Bavaria. Renewable and Sustainable Energy Reviews, 64: 248-259.

https://doi.org/10.1016/j.rser.2016.05.084

Langer, K., Decker, T., \& Menrad, K. 2017. Public participation in wind energy projects located in Germany: Which form of participation is the key to acceptance? Renewable Energy, 112: 63-73. https://doi.org/10.1016/j.renene.2017.05.021

Langer, K., Decker, T. Roosen, J., \& Menrad, K. 2018. Factors influencing citizens' acceptance and nonacceptance of wind energy in Germany. Journal of Cleaner Production, 175: 133-144.

https://doi.org/10.1016/j.jclepro.2017.11.221

Leiren, M.D., Aakre, S., Linnerud, K., Julsrud, T.E., Di Nucci, M.-R., \& Krug, M. 2020. Community Acceptance of Wind Energy Developments: Experience from Wind Energy Scarce Regions in Europe. Sustainability, 12(5), 1754. https://doi.org/10.3390/su12051754

Liebe, U., Bartczak, A., \& Meyerhoff, J. 2017. A turbine is not only a turbine: The role of social context and fairness characteristics for the local acceptance of wind power. Energy Policy, 107: 300-308.

https://doi.org/10.1016/j.enpol.2017.04.043

Liebe, U., \& Dobers, G.M. 2019. Decomposing public support for energy policy: What drives acceptance of and intentions to protest against renewable energy expansion in Germany? Energy Research \& Social Science, 47: 247-260. https://doi.org/10.1016/j.erss.2018.09.004

Lienhoop, N. 2018. Acceptance of wind energy and the role of financial and procedural participation: An investigation with focus groups and choice experiments. Energy Policy, 118: 97-105. https://doi.org/10.1016/j.enpol.2018.03.063

Ólafsdóttir, R., \& Sæpórsdóttir, A.D. 2019. Wind farms in the Icelandic highlands: Attitudes of local residents and tourism service providers. Land Use Policy, 88, 104173.

https://doi.org/10.1016/j.landusepol.2019.104173

Rand, J., \& Hoen, B. 2017. Thirty years of North American wind energy acceptance research: What have we learned? Energy Research \& Social Science, 29: 135-148. https://doi.org/10.1016/j.erss.2017.05.019

Reusswig, F., Braun, F., Heger, I., Ludewig, T., Eichenauer, E., \& Lass, W. 2016. Against the wind: Local opposition to the German Energiewende. Utilities Policy, 41: 214-227. https://doi.org/10.1016/j.jup.2016.02.006

Roddis, P., Carver, S., Dallimer, M., Norman, P., \& Ziv, G. 2018. The role of community acceptance in planning outcomes for onshore wind and solar farms: An energy justice analysis. Applied Energy, 226: 353-364. https://doi.org/10.1016/j.apenergy.2018.05.087

Scherhaufer, P., Höltinger, S., Salak, B., Schauppenlehner, T., \& Schmidt, J. 2017. Patterns of acceptance and non-acceptance within energy landscapes: A case study on wind energy expansion in Austria. Energy Policy, 109: 863-870. https://doi.org/10.1016/j.enpol.2017.05.057

Sharpton, T., Lawrence, T., \& Hall, M. 2020. Drivers and barriers to public acceptance of future energy sources and grid expansion in the United States. Renewable and Sustainable Energy Reviews, 126, 109826. https://doi.org/10.1016/j.rser.2020.109826

Songsore, E., \& Buzzelli, M. 2014. Social responses to wind energy development in Ontario: The influence of health risk perceptions and associated concerns. Energy Policy, 69: 285-296. https://doi.org/10.1016/j.enpol.2014.01.048

Sonnberger, M., \& Ruddat, M. 2017. Local and sociopolitical acceptance of wind farms in Germany. Technology in Society, 51: 56-65.

https://doi.org/10.1016/j.techsoc.2017.07.005

Sovacool, B.K., \& Ratan, P.L. 2012. Conceptualizing the acceptance of wind and solar electricity. Renewable and Sustainable Energy Reviews, 16(7): 5268-5279. https://doi.org/10.1016/j.rser.2012.04.048 


\section{Social Acceptance of Wind Energy in Urban Landscapes}

\section{Mika Westerlund}

Spiess, H., Lobsiger-Kägi, E., Carabias-Hütter, V., \& Marcolla, A. 2015. Future acceptance of wind energy production: Exploring future local acceptance of wind energy production in a Swiss alpine region. Technological Forecasting and Social Change, 101:263274.

https://doi.org/10.1016/j.techfore.2015.06.042

Steinley, D. 2006. K-means clustering: a half-century synthesis. British Journal of Mathematical and Statistical Psychology, 59(1): 1-34.

https://doi.org/10.1348/000711005X48266

Suškevičs, M., Eiter, S., Martinat, S., Stober, D., Vollmer, E., de Boer, C.L., \& Buchecker, M. 2019. Regional variation in public acceptance of wind energy development in Europe: What are the roles of planning procedures and participation? Land Use Policy, 81: 311-323.

https://doi.org/10.1016/j.landusepol.2018.10.032

Twidale, S. 2020. Green energy ratchets up power during coronavirus pandemic. The Guardian, July 22, 2020. [Available at:

https://www.theguardian.pe.ca/business/reuters/gre en-energy-ratchets-up-power-during-coronaviruspandemic-476109/]

Upham, P., Oltra, C., \& Boso, A. 2015. Towards a crossparadigmatic framework of the social acceptance of energy systems. Energy Research \& Social Science, 8: 100-112.

https://doi.org/10.1016/j.erss.2015.05.003

Vuichard, P., Stauch, A., \& Dällenbach, N. 2019. Individual or collective? Community investment, local taxes, and the social acceptance of wind energy in Switzerland. Energy Research \& Social Science, 58, 101275.

https://doi.org/10.1016/j.erss.2019.101275

Walker, B.J.A., Wiersma, B., \& Bailey, E. 2014. Community benefits, framing and the social acceptance of offshore wind farms: An experimental study in England. Energy Research \& Social Science, 3, 46-54.

https://doi.org/10.1016/j.erss.2014.07.003

Walker, C., Stephenson, L., \& Baxter, J. 2018. His main platform is 'stop the turbines' : Political discourse, partisanship and local responses to wind energy in Canada. Energy Policy, 123: 670-681.

https://doi.org/10.1016/j.enpol.2018.08.046

Westerberg, V., Jacobsen, J.B., \& Lifran, R. 2015. Offshore wind farms in Southern Europe - Determining tourist preference and social acceptance. Energy Research \& Social Science, 10: 165-179.

https://doi.org/10.1016/j.erss.2015.07.005

Wolsink, M. 2018. Social acceptance revisited: gaps, questionable trends, and an auspicious perspective. Energy Research \& Social Science, 46: 287-295. https://doi.org/10.1016/j.erss.2018.07.034
Wüstenhagen, R., Wolsink, M., \& Bürer, M.J. 2007. Social acceptance of renewable energy innovation: An introduction to the concept. Energy Policy, 35(5): 2683-2691.

https://doi.org/10.1016/j.enpol.2006.12.001

Yuan, X., Zuo, J., \& Huisingh, D. 2015. Social acceptance of wind power: a case study of Shandong Province, China. Journal of Cleaner Production, 92: 168-178. https://doi.org/10.1016/j.jclepro.2014.12.097

Zaunbrecher, B., \& Ziefle, M. 2016. Integrating acceptance-relevant factors into wind power planning: A discussion. Sustainable Cities and Society, 27: 307-314.

https://doi.org/10.1016/j.scs.2016.08.018

Wikipedia. 2020. Helsinki.

https://en.wikipedia.org/wiki/Helsinki [accessed July $21,2020]$

\section{About the Author}

Mika Westerlund, DSc (Econ), is an Associate Professor at Carleton University in Ottawa, Canada. He previously held positions as a Postdoctoral Scholar in the Haas School of Business at the University of California Berkeley and in the School of Economics at Aalto University in Helsinki, Finland. Mika earned his doctoral degree in Marketing from the Helsinki School of Economics in Finland. His research interests include open and user innovation, the Internet of Things, business strategy, and management models in high-tech and serviceintensive industries.

Citation: Westerlund, M. 2020. Social Acceptance of Wind Energy in Urban Landscapes. Technology Innovation Management Review, 10(9): 49-62. http://doi.org/10.22215/timreview/1389

Keywords: Social acceptance, wind energy, clean energy, sustainability, city 